\title{
GLACIOLOGICAL RESEARCH SUB-COMMITTEE SIXTH ANNUAL REPORT
}

21 November ${ }_{1962}$

The Glaciological Research Sub-Committee beg leave to report to the Council of the Glaciological Society on the work of the Sub-Committee for the year $196 \mathrm{I}-62$.

At its second meeting in I962, the Committee of the British Glaciological Society appointed as members of the Sub-Committee for the year I 961-62 R. J. Adie, G. R. Elliston, J. W. Glen, J. F. Nye, G. de Q. Robin, W. H. Ward, and the Chairman of the Committee of the British Glaciological Society to be a member ex officio. At that time the Chairmanship of the Society was vacant owing to the death of $\mathrm{W}$. V. Lewis; at its next meeting the Committee of the British Glaciological Society elected Sir Vivian Fuchs to that post, and his name has therefore been included as a member of this Sub-Committee.

\section{Work of the Sub-Committee}

The Sub-Committee has met twice and has dealt with many requests for assistance by correspondence. A third technical note is planned to assist expeditions in the selection of suitable glaciers for work, bearing in mind the previous work done in the various areas to which expeditions may be wishing to go. It is hoped to have this note available for circulation in the near future, and any expeditions that are considering the choice of a glacier to work on are invited to write to a member of the Sub-Committee or to the Secretary of the Glaciological Society so that they can be informed of the possibilities.

\section{REPORTS RECEIVED}

Reports have been received from the following:

British Schools Exploration Society Central Iceland Expedition I960; deposited by the Secretary of the B.S.E.S.

Cambridge Arctic Canada Expedition r96 r to Cumberland Peninsula, Baffin Island, General Report; deposited by R. E. Langford.

Cambridge Expedition to Nagir, Karakoram, r96I, General Report; deposited by W. P. Gamble.

Cambridge Expedition to Svartisen, I96I, Interim Report; deposited by W. H. Theakstone.

Imperial College Exploration Board Expedition to Øksfjordjøkulen, Arctic Norway, I96r ; deposited by $\mathrm{H}$. Lovenbury.

NORPED I96I; Report of glaciological activities (Royal Naval Colleges expedition to Austerdalsbreen); deposited by M. B. Hosford.

I96I South Greenland Expedition, Report; (work particularly on Sermitsiaq) deposited by M. R. Kelly.

The r96r University of London Beerenberg Expedition to North Jan Mayen Island, Interim Glaciological Report; deposited by D. J. J. Kinsman and J. W. Sheard.
J. W. Glen, Chairman
R. J. ADIE
G. R. Elliston

V. E. Fuchs

J. F. NYE

G. de Q. RobIN

W. H. WARD 